\title{
Study on the Police Occupational Ethics Education in New Era
}

\author{
Hua HAN \\ Doctoral Student of School of Marxism, Zhejiang University and Lecturer of Zhejiang Police Vocational Academy
}

\begin{abstract}
In the new era of socialism with Chinese characteristics, the police occupational ethics education is faced with new requirements: new demands arising from the changes of social environment, new requirements coming from the concept of law-based governance, new perspective caused by the police individual demand, and new challenges caused by the new trend of global police affairs. At present, there are mainly insufficient attention, ineffective implementation, poor performance and other issues concerning the police occupational ethics education, thus the education in the police vocational ethics must be constantly perfected by exploring the practical and feasible means in the promotion of education status, the expansion of education contents, the innovation of educational methods, the enhancement of effectiveness, etc.
\end{abstract}

Keywords-New era; Police; Police occupational ethics education

\section{INTRODUCTION}

General Secretary Jinping XI pointed out in the report of the 19th National Congress of the Communist Party of China that it is necessary to "construct a law-based government, promote the law-based administration of government, strictly standardize the fair and civilized Law enforcement, deepen the comprehensive supplementary reforms of judicial system, comprehensively perform the judicial responsibility system, and try to make the masses to feel the fairness and justice in each judicial case" for the comprehensive law-based governance in the new era. Under the background of the comprehensive law-based governance, the concept of rule by law i.e. the constitutional law is supreme and all people are equal before the law, the police organs and its law enforcement officers as the executor and maintainer of national laws must constantly enhance the police occupational ethics education, promote the vocational ethics quality of police force, and realize the standardized law enforcement to meet the requirements for the law enforcement work of police in the new era.

\section{NEW REQUIREMENTS FOR THE POLICE OCCUPATIONAL ETHICS EDUCATION IN THE NEW ERA}

China has stepped into the new era of socialism with Chinese characteristics, and the social development is faced with new contradictions and new issues, and the masses certainly will present the new expectations and requirements for the police force. The national security, social stability, fairness and justice to be maintained by the police force in the

\footnotetext{
${ }^{1}$ Jinping XI. Secure a Decisive Victory in Building a Moderately Prosperous Society in All Respects and Strive for the Great Success of Socialism with Chinese Characteristics for a New Era -- Report of the 19th National People's Congress of the Communist Party of China [R]. Beijing: People's Publishing House, November 2017.
}

course of law enforcement depend on its level of law enforcement capacity and occupational ethics. The people's police shall establish the foundation, internalize in the heart and practice in the extrinsic behavior of police strictly according to the general requirements "comprehensively enhancing the standardized, professional and occupational construction to keep the faithful to the Party, serve the people, fairly enforce the law and strictly observe the disciplines" put forward by General Secretary Jinping Xi.

Therefore, the enhancement of the police occupational ethics education and the promotion of the police's individual ethical standard are inevitable to adapt the development tendency in the new era. The police occupational ethics education refers to the activity carried by the police organs under the moral value advocacy of the Party and the State, according to the principles and standards for the people's police vocational ethics and by means of theory instillation, propaganda and guidance, practice training, model demonstration, media public opinion, etc.to cause the systematic influence on the vocational ethics consciousness, the vocational ethics level, the vocational ethics quality, the vocational ethics state, etc. of the people's police in a planned, goal-directed and organized way. The new requirements for the police occupational ethics education in the new era mainly include:

\section{A. New Issues Caused by the Changes of Social Environment}

Currently, China is experiencing the great social revolution and transformation, the reforms of economic system, social structure, science and technologies caused the profound changes in the value orientation, social morality, behavioral pattern, etc. of the people, while these changes also bring many new issues, such as the loss of ideals and conviction, the intensification of the social contradictions, the changes in the working mode in the information and intelligence era. The original content system, ways, methods, etc. for the police occupational ethics education should be accordingly adjusted under such background. 


\section{B. New Requirements Coming form the Concept of Law- based Governance}

The law-based governance is the core content of the socialist legal governance, and it is necessary to adhere to the actions in strict accordance with law, promote the scientific legislation, strict law enforcement, fair judicature and public compliance with the law for the comprehensive law-based governance according to the requirements in the report of the 19th National Congress of the Communist Party of China. The people's police must strictly abide by the rules of law and procedures, and adhere to the equality before the law in the course of law enforcement under the concept of law-based governance. The people's police must abandon the thinking of ruling by man and privileges, establish the thinking of lawbased governance strictly according to the law, scrupulously abide by and guarantee the human rights, and integrate the socialist concept of the rule of law into the concept of law enforcement by the people's police.

\section{New perspective brought by the police individual demand}

Currently, the society is being transformed, the public security situation is severe, the tasks to maintain the stable society are obviously increased, the grass-roots police is faced with the high strength, fast and overloaded work pressure for a long time, and their physical and psychological health are worrisome. As the law-enforcing environment becomes complex, the violent resistance against law and the violent attack towards police frequently occur, and behaviors of abusing and falsely charging against the law-enforcing police, the legitimate law enforcement right of the grass-roots police can't be guaranteed. The police force appears the occupational burnout, decreased sense of achievement and honor, low sense of occupational self-identity and other phenomena, indicating that the police's individual demand shall be given more attention and satisfaction. The individual demands for the mentality, emotion, occupational development, etc. of the police must be considered in police vocational ethics education to change the traditional mode of one-way, closed and imparted police occupational ethics education and give a new perspective on the communications, open and initiative.

\section{New challenges caused by the new trend of global police affairs.}

China shall build a global view and clearly see the trend and long-term tendency of world development in the new era, our modern police shall be based on the China's national condition, but also pay attention to and imitate the world police's development theory and practice to enhance the international cooperation and exchanges and intensify the globality and forward looking of the police work. The police is faced with higher requirements for the occupational quality and the specialized technical level, and the police occupational ethics education shall approach the technical revolution, knowledge update, data sharing and other new challenges.

\footnotetext{
${ }^{2}$ We shall keep the faithful to the Party, serve the people, fairly enforce the law and strictly observe the disciplines People's Daily (06 Version of June 2, 2017)

${ }^{3}$ Editor-in-chief Lei XIONG, Zhengrong GONG. Occupational Ethics of the People's Police [R]. Beijing: China Renmin University Press, September 2014.
}

\section{CURRENT ISSUES IN THE POLICE OCCUPATIONAL ETHICS EDUCATION}

\section{A. Insufficient Attention to the Police Occupational Ethics Education}

The police occupational ethics education covers the public security and justice college education and the in-service police training education, and the college education is supplemented by the in-service training. The occupational ethics hasn't been adequately stressed in the public security and justice colleges, for example the course setting, there is no special course related to the police occupational ethics education in the public security and justice colleges, while such educational content is generally included in the courses of political and ideological theory and featured by the short class hour and absence of the practice training course related to the police occupational ethics. The in-service police training mainly emphasizes on the specialized knowledge, occupational ability and other police skills without the enough attention to the police occupational ethics education. Although the "police occupation formative education" and the "core value of people's police" are included in the content of police training as per the Regulations of Training the People's Police in the Public Security Institutions, it is still in the state under which its discussion is important, its implementation is secondary, and it is can be abandoned in the busy work.

\section{B. Ineffective Implementation of Police Occupational Ethics Education}

At present, the police occupational ethics education is mainly offered by the teachers in the public security and justice colleges and the part-time instructors in the industry. Because the teachers in the public security and justice colleges haven't close contact with the front line and are short of enough realization about the practice of public security and justice and the practical teaching ability, thus their teaching content cannot always solve the actual issues to be encountered by students in their actual work. Although the part-time instructors have rich practical experience, they are short of the experience refining and reflection without higher theoretical level and easily ignore the flexibility and pertinence of occupational ethics, the teaching means and methods should be further improved. The teachers of the police occupational ethics education who not only understand the theoretical knowledge, but also have the practical experience are absent due to the particularity of establishment and identity, the industrial boundedness in the public security and justice colleges and other factors.

\section{Poor Performance of Police Occupational Ethics Education}

At present, the teaching materials used in the police occupational ethics education are generally the self-compiled materials or lecture notes of the public security and justice colleges or the training institutions, they are short of resource sharing, exchanges and cooperation with other colleges and can't imitate the research achievements in other humanities. The police occupational ethics education is generally implemented by the instructions or lectures offered by teachers, such one-way and untargeted closed education mainly focused 
on the instructions or lectures is very difficult to mobilize the learning interest and independent thinking of students.

\section{PERfECt THE MeANS OF Police OCCUPATIONAL ETHICS EDUCATION}

\section{A. Promote the Status of Police Occupational Ethics Education}

To enhance the occupational ethics education of the police force is an important means for innovating the ideological and political construction by the police organs under the new situation. Relevant functional departments shall pay attention to the police occupational ethics education, all departments shall give full cooperation to increase the input into the teachers, fund, class hours and other aspects relating to the courses of the police occupational ethics education, perfect the textbook compilation, instructor training, teaching practice and other links. The teachers and instructors of specialized knowledge, police skills, practical training and other relevant courses can penetrate the police occupational ethics education into the respective course to cultivate their occupational ethics spirit at the time of promoting the students' skill quality. The student management department of the public security and justice colleges can carry out implicit occupational ethics edification through internship and probation, policing management and campus culture construction, so that students can complete the process of cognition, experience, formation and internalization of police occupational ethics in on-campus and off-campus practices.

\section{B. Expand the Content of Police Occupational Ethics Education}

The content of police occupational ethics education now focuses on the code of occupational ethics. For example, the content of the Code of Occupational Ethics for People's Police in Public Security Organs revised by the Ministry of Public Security in 2011 has been expanded from the original eight articles to ten articles, including three aspects of political requirements, occupational quality and style of discipline required by the police occupation. We can't simply interpret these ten norms as all content of police occupational ethics under the new situation. The higher and higher requirements for the standardization of police law enforcement are made in the new era, and the police occupational ethics education shall be expanded according to new situations and new issues encountered in the current law enforcement practice of basiclevel police. Adjust and expand the teaching contents according to different ages, different occupational stages and different categories of alarm posts, set corresponding case teaching and practical training contents, and highlight the targeted, practical and forward-looking training contents.

The attention shall also be paid to the psychological needs of police individual in the education, and meanwhile the psychological education, emotional education and other contents shall be integrated into the police occupational ethics education. Although intellectual and skilled law enforcement norms tell the police what should be done, and what shouldn't be done in the process of law enforcement, but to each police

\footnotetext{
${ }^{4}$ Yuejiao BAI. Issues and strategies of police occupational ethics education in public security colleges under the new situation $[\mathrm{J}]$. Journal of Shanxi Police College 2017(2)

${ }^{5}$ Analysis of points of the newly revised Regulations of Training the People's Police in the Public Security Institutions

http://www.chinapeace.gov.cn/2014-12/08/content_11157343.htm.
}

officer and each case, the individual law enforcement behaviors are gradually formed during the specific law enforcement interaction. They will be inevitably affected by the psychological factors such as the cognition, emotion, personality and values of the police individuals, which will affect the law enforcement effect of the police. Therefore, we shall also pay attention to the needs of police individuals and expand relevant knowledge while paying attention to the regulative principles of police groups.

The content of police occupational ethics education shall conform to the trend of the times. Under the background of globalization, informationization and intellectualization, the police occupational ethics education shall expand horizons, constantly update education contents according to new problems under the new situation, attach importance to the power of the media and guidance of public opinion, strengthen the propaganda and occupy new positions of ideological and political education. On the one hand, establish regular and irregular training mechanisms according to the social hot issues, on the other hand, encourage the police to actively learn techniques and the development of new media, fully and effectively use new media to raise their occupational ethics and quality, enabling them to obtain correct and scientific concept guide and to constantly improve the level of occupational ethics.

\section{Innovate the Method of Police Occupational Ethics Education}

At present, the police occupational ethics education starts from the learning stage after the students enter the police school or the pre-job training stage after the new police officer is employed. However, the individual's motivation, needs, values and others have been formed before they become police school students or police officers. Therefore, the police occupational ethics education can be moved forward and shall be combined with the police recruitment system. The attention shall be paid to the assessment of political literacy in the selection and appointment of police officers, and their recognition and loyalty to the occupation shall be investigated. The motivation of becoming a police officer determines the occupation attitude of a police officer and also affects the career of a police officer. Currently, many practical problems reflected in the police school students and the police force aren't caused by the ability but attitude. In the long run, the stability and happiness of the police occupation also come from the motivation of becoming a police officer and values.

We shall reform the teaching method and strengthen the practical education and participative teaching in the course teaching. We shall attach importance to the application of case teaching, interactive teaching and discussion teaching, highlight students' subjective initiative, change passive indoctrination into active thinking, pay close attention to students' learning state, and enable students to really participate in the course. We shall carry out in-depth practice and exploration, change students' thinking mode and learning method in the continuous spiral escalation of theory and practice, extend the intracurricular teaching to extracurricular teaching, and make the requirements of police occupational ethics concrete, realistic and long-term. 
In the face of the complicated social reality, we shall strengthen the police occupational ethics education, can't neglect the leading and demonstration role of examples and dual identity of teachers in the public security and justice college as a teacher and a police officer, give full play to the example function of teachers, captains and other school management personnel. Educators shall strengthen the persuasion of occupational ethics education and deepen students' understanding of the police occupational ethics with their spirit of dedication and examples around them. There are a large number of epic advanced figures and outstanding occupational ethics models in the people's police force, who shall be honored strongly and propagandized through deeds report of excellent figures, advertising video, film and other ways. The guiding role of excellent cultural works shall be played, enabling students to feel the occupational ethics spirit of excellent people's police and achieving the purpose of motivating and educating people.

\section{Enhance the Effectiveness of Police Occupational Ethics Education}

The effectiveness of police occupational ethics education can only be tested in practice. The public security and justice colleges can make the police occupational ethics consciousness into the students' daily life through various ways in practice and strengthen the police awareness of students with the house keeping standardization requirements, high strength formation training, strict leave and cancellation system and other policing management systems, so that students can develop discipline obedience consciousness and shape the police professionalism. They can build up the students' physical quality and temper psychological quality and teamwork spirit through physical training and police physical training classes as well as various sports activities and competitions. They can provide the opportunity for the practice of students' occupational ethics and situate the occupational moral education in the construction of campus culture through the district team, students' union and club activities, discuss the police occupational values, stimulate the patriotic enthusiasm and spirit of utter devotion of police school students and cultivate their love of the police occupation through organizing public welfare activities, poetry reading, debate competition, speech contest, career planning competition and other campus cultural activities.

They can provide students with practical opportunities through internship and probation, security duty and other practical police activities. The public security and justice colleges shall strengthen cooperation with the public security and justice departments, and expand the probation and practice bases outside school. Students can experience the police occupation directly in the internship position, understand the actual situation of the post of duty, feel the sense of achievement and value of the police work in the police practice, cultivate the occupational ethics quality and enhance the practicalness and guidance of occupational ethics education. Through the above practice activities, students can understand the purpose and significance of the activities, give play to their subjective role, and carry out the self-management and selfeducation in practice, thus unconsciously internalizing and externalizing the police occupational ethics education in their minds and their actions respectively.

\section{E. Perfect the Theory of Police Occupational Ethics Education}

For further development of police occupational ethics education, a strong theoretical foundation is firstly required. With lack of mature theory of police occupational ethics education in China, perfect system and deep research, we must be based on the realistic background of new era of socialism with Chinese characteristics, the career development of basiclevel police in China and the work practice of police occupational ethics education and use the theory of Marxism and method to further excavate the connotation of police professionalism, so that we can find the law of development of police occupational ethics education in China and build a perfect theory system. The scientificity of the theory of police occupational ethics education shall be tested in the practice of police work. Only the theory valuable to the construction of the police force can enhance the self-feeling and sense of honor of the police force, and truly make the occupational spirit of police become the highest ideal pursuit of the people's police.

For further development of police occupational ethics education, the police law enforcement environment and other external factors need to be improved and the guarantee of the police law enforcement rights, maintenance of the police law enforcement authority, and elimination of the worries of the police law enforcement are required from top to bottom from the angle of conceptual design. The improvement of law enforcement environment also requires correct public opinion guidance. The police team shall improve its occupational quality when facing the media, release information objectively, accurately and timely in the face of emergencies, guide public opinion actively and effectively, and avoid the public speculation and rumors. The most important thing to improve the law enforcement environment is to strengthen the law education of the police. It is necessary to master the related legal knowledge, take law as the criterion, improve the legal literacy and law enforcement ability of the law executors, and ensure law enforcement according to law, so as to constantly meet the new expectations and requirements of broad masses of the people under the new era.

\section{CONCLUSION}

In the new era of socialism with Chinese characteristics, there are still many issues in the current police occupational ethics education due to the changes of social environment, deepening of the concept of law-based governance, appeal of police individual needs and development of the global trend of police. We must base upon circumstance, look to the future and make the corresponding adjustment according to the requirements of the development of the new era. In my opinion, it can be improved from the following aspects: Improve the status of police occupational ethics education, expand the contents of police occupational ethics education, create the method of police occupational ethics education and enhance the effectiveness of police occupational ethics education, etc.

${ }^{6}$ Editor-in-chief Lei XIONG, Zhengrong GONG. Occupational Ethics of the People's Police [R]. Beijing: China Renmin University Press, September 2014. 


\section{REFERENCES}

[1] Editor-in-chief Lei XIONG, Zhengrong GONG. Occupational Ethics of the People's Police [R]. Beijing: China Renmin University Press, September 2004.

[2] Yuejiao BAI. Issues and strategies of police occupational ethics education in public security colleges under the new situation $[\mathrm{J}]$. Journal of Shanxi Police College 2017(2).

[3] Jinping XI. Secure a Decisive Victory in Building a Moderately Prosperous Society in All Respects and Strive for the Great Success of Socialism with Chinese Characteristics for a New Era -- Report of the 19th National People's Congress of the Communist Party of China [R]. Beijing: People's Publishing House, November 2017.

[4] We shall keep the faithful to the Party, serve the people, fairly enforce the law and strictly observe the disciplines People's Daily (06 Version of June 2, 2017).

[5] Lili YANG Research on the existing issues and countermeasures of the present occupational ethics of the people's police [J]. Legality Vision, 2016 (2).

[6] Xiaoming YANG. Discussion on the code of occupational ethics of American police and its enlightenment to our country [J]. New West, 2014(9).

[7] Editor-in-chief Yanji WANG, Chinese and Foreign Police Education and Training [R]. Beijing: China Renmin University Press, October 2011.

[8] Editor-in-chief Yuanchao LIU, Police Psychological Education [R]. Tianjin: Tianjin Academy of Social Sciences Press, February 2008. 